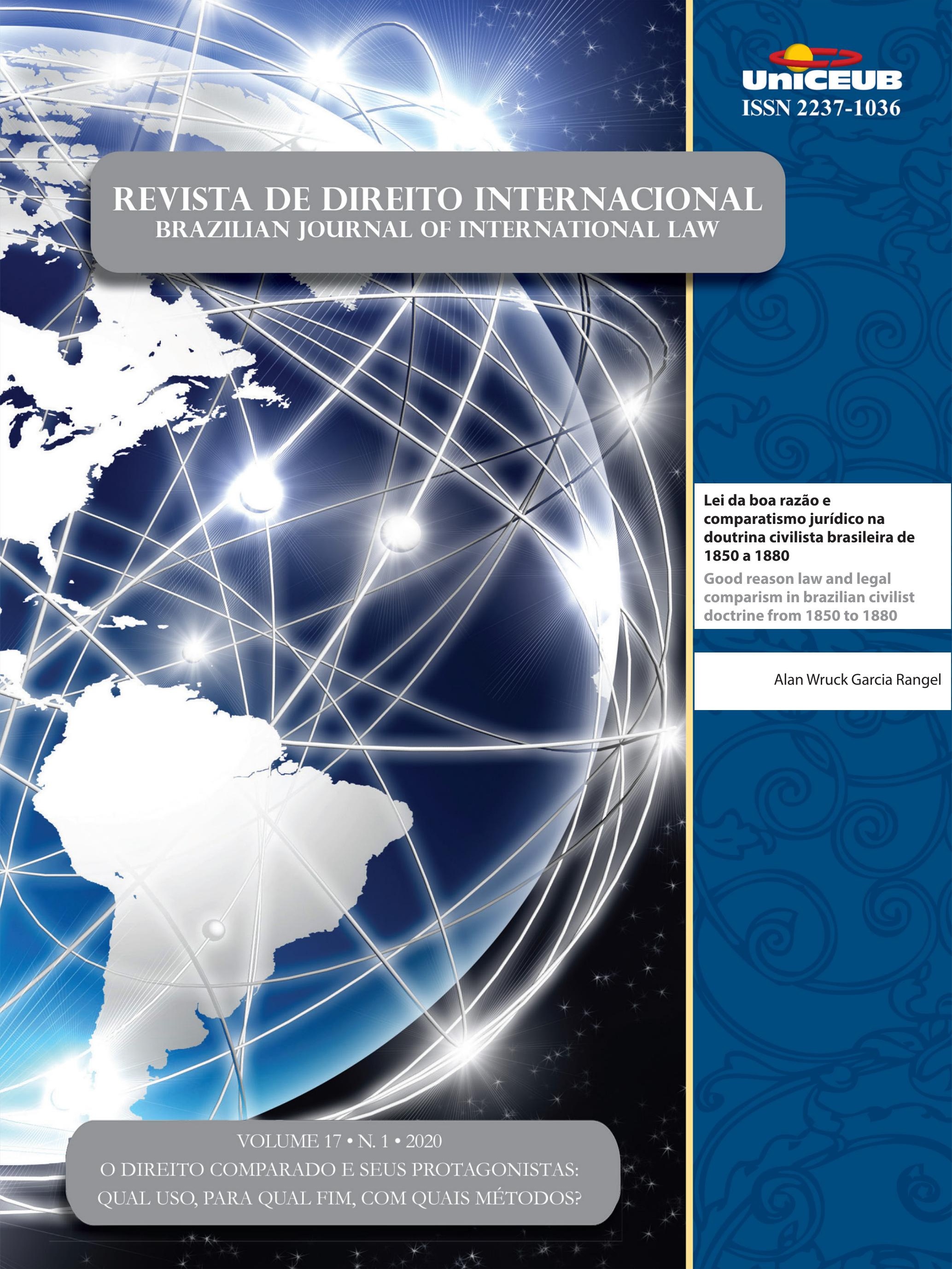


Parte I - O Direito comparado e seus Protagonistas: QuAL uso, PARA QUAL FIM, COM QUAIS MÉTODOS? .....................................................................1

EDITORIAL ............................................................................................................... 3

"Tudo o que precisamos fazer é ter certeza de que continuaremos conversando".............................. 3

Gustavo Cerqueira e Patrícia Perrone Campos Mello

Direito comparado E METOdologia $\quad$................................................... 6

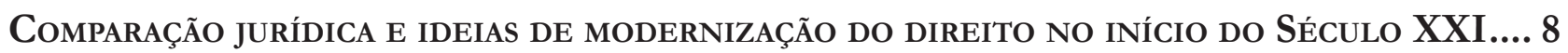
Gustavo Cerqueira

O DIREITO COMPARADO: ESFORÇO DE RESGATE HISTORIOGRÁFICO E DE PROBLEMAS METODOLÓGI$\cos$

Arnaldo Sampaio de Moraes Godoy e Gustavo Fereira Ribeiro

Direito Comparado e Política: Reflexões Necessárias .42

Raphael Carvalho de Vasconcelos e Deo Campos Dutra

Direito comparado no Brasil

L'originalité du Droit Brésilien et le Droit Comparé .57

Arnoldo Wald

LEI DA BOA RAZÃo E COMPARATISMO JURÍDICO NA DOUTRINA CIVILISTA BRASILEIRA DE 1850 A 1880

Alan Wruck Garcia Rangel

O STF EM REDE? QUANTO, COMO, COM QUE ENGAJAMENTO ARGUMENTATIVO O STF USA PRECEDENTES ESTRANGEIROS EM SUAS DECISÕES?

Patrícia Perrone Campos Mello e Felipe Meneses Graça 
Suprema Imprecisão: a metodologia em Direito Constitucional Comparado E as deficiênCias Em Seu uso pelo Supremo Tribunal Federal

Alonso Freire e Hugo Sauaia

Direitos comparados

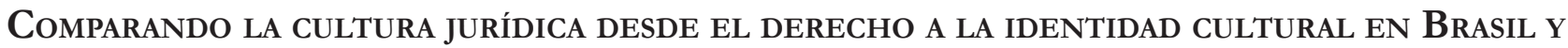

CHILE 145 Juan Jorge Faundes e Fabian Le Bonniec

O Divino e o Racional no Direito: notas para um diálogo entre sistemas jurídicos 181 Salem Hikmat Nasser e José Garcez Ghirardi

Regulação do discurso de Ódio: análise comparada em países do Sul Global 196 Jane Reis Gonçalves Pereira, Renan Medeiros de Oliveira e Carolina Saud Coutinho

Parte II - Outros temas

LA OTRA CARA DE LA MONEDA: PROTECCIÓN CONSTITUCIONAL DE LA EMPRESA, EL EMPRENDIMIENTO Y LA LIBRE COMPETENCIA EN CHILE y COLOMBiA

Juan Pablo Díaz Fuenzalida e Juan Sebastián Villamil Rodríguez

The European Court of Human Rights Decision on there 'Burqa Ban'and the CritiCal analysis of the Pragmatic experimental logic 258 Flavianne Fernanda Bitencourt Nóbrega e George Browne Rego

Direitos humanos das deslocadas ambientais e os impactos da Usina de Belo Monte: da EXPLORAÇÃO AMAZÔNICA À SUBJUGAÇÃO FEMININA

Thais Silveira Pertille e Letícia Albuquerque

Solução de Controvérsias em Acordos de Investimento: as experiênCias do CPTPP, CETA E DOS ACFIs

Fábio Morosini, Vivian Daniele Rocha Gabriel e Anastacia Costa

50 anos dos “direitos da Criança” na Convenção Americana de Direitos Humanos: a HISTÓRIA DO ARTIGO 19 311

Sven Peterke e Paloma Leite Diniz Farias 
EMPRESAS E DIREITOS HUMANOS: COMPARTILHANDO VALOR E RESPONSABILIDADES .325 Melina Girardi Fachin

CONTEMPORARY RESPONSES TO BUSINESSES' NEGATIVE HUMAN RIGHTS IMPACT 341 Andres Felipe Lopez

Human Right to LABOR PROTECTION IN UKRAINE: CURRENT SITUATION AND THE PROSPECTS OF IMPLEMENTATION OF INTERNATIONAL RULES 363 Nina Daraganova

International Regulation and Global Governance: The EU influential Method IN TIMES OF NORMATIVITY CHANGE 373 Gabriela Hühne Porto, Paula Wojcikiewicz Almeida e Juliana Maia F. A. Netto

Tecnologias digitais e o comércio de bens E SERviços na OMC/Digital. 391 Umberto Celli Junior

Los fuertes hacen lo QUe PUeden: exponiendo los límites de la Corte Penal InternaCIONAL .406

Cristián D. González-Ruiz e Víctor M. Mijares

Human Rights, Humanitarian Law and State Power 418 Renata Nagamine e João Roriz

Regional integration in the South Pacific: Challenges for Public governance .433 Joanna Siekiera

Parte III - Resenhas 443

RESENHA DA OBRA

“Democracia e policentrismo do poder", de Murilo Gaspardo 445 Angela Limongi Alvarenga Alves 


\title{
Lei da boa razão e comparatismo jurídico na doutrina civilista brasileira de 1850 a $1880^{*}$
}

\author{
Good reason law and legal comparism in \\ brazilian civilist doctrine from 1850 to 1880
}

Alan Wruck Garcia Rangel ${ }^{* *}$

* Recebido em 02/01/2020

Aprovado em 06/05/2020

O presente artigo é fruto de comunicação oral apresentada no congresso "A função modernizadora do direito comparado - 250 anos da Lei da Boa Razão". Agradeço aos organizadores por permitir o envio desta versão escrita à presente publicação. Registro, igualmente, meus sinceros agradecimentos à professora Iacyr Aguiar Vieira pela leitura atenta e comentários da versão inicial do texto, e ao professor Alfredo de Jesus Dal Molin Flores pelos preciosos apontamentos durante minha exposição no Grupo de trabalho "Transferências, Transplantes, Tradução Cultural”, no XI Congresso Brasileiro de História do Direito.

** Pesquisador em estágio pós-doutoral no Laboratório Interdisciplinar de História do Direito da Universidade do Estado do Rio de Janeiro (LIHD-UERJ). Foi bolsista do CNPq pelo programa Pós-Doutorado Júnior (20172018). Atualmente, é bolsista da FAPERJ pelo programa Pós-doutorado Nota 10 com projeto de pesquisa intitulado "O direito de correção antes do Código de menores de 1927". Tem doutorado em História do Direito e das Instituições pela Universidade de Estrasburgo, França (2016). Mestre em História do Direito pela Universidade de Montpellier I (2008), França. Graduado em Direito Comparado pela Faculté Internationale de Droit Comparé (2009). Foi bolsista do Programa de bolsas de excelência do Ministério dos Negócios Estrangeiros francês (2007), e do Programa de bolsas de alto nível da União Europeia para América Latina (2006). Foi, igualmente, Attaché temporaire d'enseignement et recherche (Professor substituto) nas Faculdades de Direito da Universidade de Estrasburgo e Universidade La Rochelle, ambas na França. Atualmente, leciona, no âmbito do pós-doutorado, no curso de graduação da Faculdade de Direito da UERJ. É membro da Société d'Histoire du Droit (SHD). Desenvolve pesquisa nas áreas História do Direito Privado, Direito Privado Comparado, Teoria Geral do Direito, História do Direito Social. Email: alan.wruck@gmail.com

\section{Resumo}

Estudos indicam o ano de 1900 como marco inicial do direito comparado enquanto ciência autônoma. O presente artigo propõe que a comparação jurídica, como atividade intelectual, já existia nos escritos dos juristas ao final do século XIX, e toma-se como exemplo a doutrina civilista. Propõe, ainda, que o comparatismo está enraizado na doutrina brasileira, esta constituída após a Lei da Boa Razão de 1769 que havia reformado o ensino jurídico em Portugal. O recurso ao direito estrangeiro faz, portanto, parte da formação jurídica dos primeiros juristas brasileiros nas Faculdades de Olinda (a partir de 1854 em Recife) e São Paulo. Apoiada no conceito de "boa razão", a doutrina perfilha a ideia de que fontes do direito externo são mais adiantadas e modernas, e podem ser aplicadas para preencher lacunas do direito nacional.

Palavras-chave: Lei da Boa Razão; Direito Comparado; Direito Civil; Doutrina Civilista; Uso do Direito Romano.

\section{Abstract}

Studies point to the year 1900 as the starting point of comparative law as an autonomous science. This article proposes that legal comparison, as an intellectual activity, already existed in the writings of jurists of the late nineteenth century, and civilist doctrine is taken as an example. It also proposes that comparatism is rooted in Brazilian doctrine, which was established after the "Good Reason Law" of 1769 that had reformed legal education in Portugal. The use of foreign law is, therefore, part of the legal formation of the first Brazilian jurists at the Faculty of Law of Olinda (from 1854 in Recife) and São Paulo. Supported by the concept of "good reason", the doctrine supports the idea that sources of foreign law are more advanced and modern, and can be applied to fill gaps in national law.

Keywords: Good Reason Law; Comparative Law; Civil Law; Civilist Doctrine; Use of Roman Law. 


\section{Introdução}

A comparação jurídica na cultura luso-brasileira se desenvolve, inicialmente, no esquema das fontes subsidiárias do direito ${ }^{1}$. Está essencialmente fundada na ideia de que existe uma fonte externa capaz de elaborar uma interpretação moderna das soluções encontradas no Corpus Iuris Civilis. O uso moderno do direito romano (usus modernus pandectarum) constitui, assim, uma doutrina específica que emerge no século XVI com o humanismo jurídico (mos gallicus) ao preconizar o seu estudo científico, erudito, com explicações racionais organizadas de maneira sistemática ${ }^{2}$. Isto significava o retorno às suas fontes originais e a varredura dos inúmeros comentários, muitas vezes confusos, acumulados até então pelos escritos da doutrina do mos italicus cujo maior representante foi Bártolo ${ }^{3}$. Os principais representantes do humanismo jurídico - Cujácio, Alciato, Hotman - deixaram seguidores por toda a Europa, de modo que se desenvolve com maior ou menor intensidade nos séculos seguintes, até encontrar alto grau de sofisticação nos pandectistas alemães do século XIX. As Ordenações Filipinas haviam aberto, no século XVII, uma brecha à entrada dessa doutrina moderna em Portugal quando permitem, de modo subsidiário, a aplicação do direito romano "conforme à boa razão". A falta de efetividade dessa legislação levou o monarca português a repeti-la no século XVIII e, ao mesmo tempo, a criar novos critérios e possibilidades por intermédio da expressão "nações civilizadas". Com pretexto de estancar de modo permanente o uso abusivo da doutrina es-

Rui Manuel de Figueiredo Marcos, A legislação pombalina. Alguns aspectos fundamentais. Coimbra: Almedina, 2006, p. 153 e s.; Mário Júlio de Almeida Costa ; Rui Manuel de Figueiredo Marcos, "A reforma pombalina dos estudos jurídicos", Boletim da Faculdade de Direito, vol. LXXV, Universidade de Coimbra, 1999, p. 67-98; Guilherme Braga da Cruz, O direito subsidiário na bistória do direito português, Obras esparsas, volume II. Estudos de História do Direito, Coimbra, 1981, p. 279 e s.

2 A bibliografia sobre o humanismo jurídico é imensa. Para uma primeira abordagem, cf. Jean-Marie Carbasse, Manuel d'introduction bistorique au droit. Paris: Puf, 2001, p. 146 e s.; ver também, Michel Villey, La formation de la pensée juridique moderne. Paris: Quadrilage Puf, 2006, p. 382-487. Houve resistência, tanto em Portugal como na Espanha, à penetração da doutrina de autores franceses durante os séculos XVI e XVII, como já demonstrado em estudo de caso sobre a obra de Jean Bodin, cf. Martim de Albuquerque, Jean Bodin na península ibérica. Ensaio de história das ideias políticas e de direito público. Paris: Fundação Calouste Gulbenkian, 1978.

3 Martim de Albuquerque, "Bártolo e bartolismo na história do direito português", Estudos de cultura portuguesa, $1^{\circ}$ Volume. Lisboa: Imprensa nacional-Casa da moeda, 1983, pp.41-123. colástica (glosadores e pós-glosadores), a Lei de 18 de agosto de 1769, conhecida, posteriormente, como Lei da Boa Razão ${ }^{4}$, reforma o sistema de direito subsidiário das Ordenações Filipinas, e amplia, consideravelmente, o antigo conceito de "boa razão". Doravante, não se trata, apenas, de recorrer à doutrina moderna do direito romano, mas também da possibilidade de aplicação, enquanto fonte subsidiária do direito pátrio, dos "Codigos das Nações Estrangeiras mais civilizadas, e vizinhas", estas reputadas como "muito mais adiantadas..." abertura ao direito estrangeiro, pela ampliação do conceito de "boa razão", teve efeito considerável no Brasil. Permitiu que a doutrina do século XIX se formasse apoiada na ideia de que as fontes do direito estrangeiro são mais adiantadas e modernas, e podem ser aplicadas para preencher lacunas do direito nacional ${ }^{6}$.

É, portanto, a partir dessa regulamentação do quadro das fontes do direito, prevista na Lei da Boa Razão, que se pretende examinar o desenvolvimento do comparatismo na doutrina civilista brasileira do século $\mathrm{XIX}^{7}$. O objetivo é saber como os juristas interpretaram o estoque conceitual e o conjunto normativo dessa lei na parte remissiva ao direito estrangeiro. A estratégia metodológica reside, portanto, na análise de conteúdo ${ }^{8}$ dos textos de doutrina a fim de conhecer a imagem que os juristas tinham acerca das fontes que utilizavam, notadamente daquelas produzidas no direito estrangeiro. Trata-se de estudo que tenta historiar o direito comparado na sua dimensão científica ${ }^{9}$, o que implica reperto-

\footnotetext{
4 A expressão "Lei da Boa Razão" foi cunhada em 1824 pelo jurista português José Homem Corrêa Telles na sua obra Commentário crítico à Lei da Boa Raz̃ão. Lisboa: Typographia de Maria da Madre de Deus, $1^{a}$ edição de 1824 (no presente estudo utilizamos a edição de 1865).

5 Memorias de litteratura portugueza, publicadas pela Academia Real das Sciencias de Lisboa, t. 1. Lisboa: Officina da Academia Real de Sciencias, 1782, §LIV, p. 328.

6 Com abordagem diversa da nossa, os diversos usos do direito estrangeiro pelo jurista brasileiro foi estudado em Airton Seelaender, A doutrina estrangeira e o jurista brasileiro: usos, estratégias e recriações. In: Carolina Alves Vestena; Gustavo Silveira Siqueira. (Org.). Direito e experiências jurídicas- Temas de história do direito. 1ed. Belo Horizonte: Arraes, 2013, v. 3, p. 1-17.

Este trabalho está em conexão com estudo anterior sobre o comparatismo no projeto de código civil de Teixeira de Freitas, cf. Alan Wruck Garcia Rangel, "O projeto de Teixeira de Freitas: um código civil antinapoleônico ? Contribuição ao estudo do comparatismo jurídico no século XIX”, Arno Wehling, Gustavo Siqueira, Samuel Barbosa (orgs.), História do direito. Entre rupturas, crises e descontinuidades. Belo Horizonte: Arraes, 2018, p. 165-183.

8 Laurence Bardin, L'analyse de contenu. Paris: Presses universitaires de France (Quadrilage), 2013.

9 Abordagem semelhante, para o direito italiano, em Francesco Aimerito, "La comparaison comme méthode d'élaboration des lois au
} 
riar os quadros argumentativos e esquemas interpretativos dos juristas brasileiros no período indicado. Não extraí dos seus escritos informação bruta, a partir da contagem de fontes citadas no texto, e procurei, simplesmente, confrontar as intenções expressas dos autores quanto ao método de exposição e uso da fonte estrangeira ${ }^{10}$. Compulsei as obras publicadas entre 1850 e 1880, período anterior à reforma Benjamim Constant (decreto n. ${ }^{\circ} 1232-\mathrm{H}$ de 2 de janeiro de 1891) ${ }^{11}$ que criou a cadeira de "Legislação comparada sobre o direito privado", cujo primeiro professor foi Clovis Bevilaqua ${ }^{12}$. Utilizei, portanto, as seguintes obras: Lourenço Trigo de Loureiro, Instituições de direito civil brasileiro, primeiro livro publicado no Brasil na matéria ${ }^{13}$; Augusto Teixeira de Freitas, Consolidação das leis civis ${ }^{14}$; Agostinho Perdigão Malheiros, A escravidão no Brasil. Ensaio bistórico-jurídico-social ${ }^{5}$, e seu opúsculo Commentário à lei n..$^{\circ} 463$ de 2 de setembro de 1847 $7^{16}$; Lafayette Rodrigues, Direitos de família ${ }^{17}$ e Antonio Joaquim Ribas, Curso de direito civil $^{18}$.

XIXe siècle: le cas de l'Italie (1814-1866)", Clio@Thémis, n. ${ }^{\circ}$ 13, 2017. 10 Apesar de nos ter inspirado, nos distanciamos ligeiramente da metodologia adotada em António Manuel Hespanha, "Razões de decidir na doutrina portuguesa e brasileira do século XIX. Um ensaio de análise de conteúdo", Quaderni Fiorentini per la storia del pensiero giuridico moderno, n. ${ }^{\circ} 39,2010$, p. 109-151.

11 O decreto do "ensino livre" de 1879 evoca a atividade de comparação de maneira incidente ao prever que o estudo do direito constitucional, criminal, civil, comercial e administrativo seja sempre "acompanhado da comparação da legislação patria com a dos povos cultos” (Art. 23, $\$ 5^{\circ}$, decreto n. ${ }^{\circ} 7.247$ de 19 de abril de 1879, Collecção das leis do Império do Brasil, vol. 1, Parte II, 1879. Rio de Janeiro: Typographia nacional, p. 209).

12 Alberto Venâncio Filho, Das arcadas ao bacharelismo. São Paulo: editora perspectiva, 1977, p. 177. Antes da criação desta cadeira, a comparação jurídica - ainda que circunscrita à legislação - não havia se especializado enquanto ciência nas faculdades de direito. Para Bevilaqua, com a criação dessa cadeira, a comparação deixa de ser "accidente", "accessorio", e passa a ser "o systema, ...a substância mesma do assumpto" (Clovis Bevilaqua, Resumo das lições de legislação comparada sobre o direito privado. Recife: Typographia de F. P. Boulitreau, 1893, p. 3).

13 Lourenço Trigo de Loureiro, Instituições de direito civil brasileiro, 2 tomos. Rio de Janeiro: Garnier, $3^{\mathrm{a}}$ ed., 1871 [1ª ed. 1851].

14 Augusto Teixeira de Freitas, Consolidação das leis civis, publicação autorisada pelo governo, $3^{a}$ edição mais augmentada, Rio de Janeiro: B. L. Garnier, Livreiro editor do Instituto Histórico, 1876. Doravante: CLC.

15 Agostinho Marques Perdigão Malheiros, A escravidão no Brasil. Ensaio histórico-jurídico-social, 3 vols. Rio de Janeiro: Typographia Nacional, 1867.

16 Agostinho Marques Perdigão Malheiros, Commentário à lei n. ${ }^{\circ} 463$ de 2 de setembro de 1847 sobre successão dos filhos naturaes e sua filiação. Rio de Janeiro: Eduardo e Henrique Laemmert, 1857.

17 Lafayette Rodrigues Pereira, Direitos de família. Rio de Janeiro: typographia franco-americana, 1869.

${ }_{18}$ Antonio Joaquim Ribas, Curso de direito civil, 2 vols. Rio de Ja-
É lugar comum na historiografia considerar o primeiro Congresso internacional de direito comparado de 1900, realizado em Paris, como o momento da "tomada de consciência" sobre a autonomia do direito comparado enquanto ciência. Há consenso de que, a partir desse congresso, organizado por Raymond Salleiles, à época Professor da Faculdade de Direito de Paris, se determina a criação de método científico específico. Antes desse encontro, afirmam os historiadores do direito, a análise comparativa era, excessivamente, superficial, de sorte que os "juristas se interessavam únicamente por la comparacón de legislaciones..., sin que hubiese un interés por el derecho entendido como fenómeno que superaba el soporte textual de los códigos y que incluía la jurisprudencia y la doctrina"19. Com efeito, a comparação legislativa ganha contornos próprios dentro do movimento de codificação que se instala na Europa, para situar o direito positivo no centro do quadro de fontes. Entretanto, se, consideramos que, em alguns países, certos ramos do direito tiveram uma codificação bem tardia - a exemplo dos códigos civis da Alemanha (1900) e do Brasil (1916) —, durante o período de ausência de código, vigorava o pluralismo jurídico, o que nos leva a relativizar a ideia de que a atividade intelectual desses juristas se dava unicamente pela "comparación literal de textos legales de países distintos"20. Nessa paisagem jurídica plural, não só a legislação, mas também doutrina e decisões judiciais estrangeiras poderiam ser mobilizadas e tratadas como fonte jurídica aplicável de modo acessório ao direito pátrio ${ }^{21}$.

A Lei da Boa Razão, elaborada em Portugal no quadro do despotismo ilustrado da segunda metade do século XVIII, fruto da política reformista levada a cabo por Marquês de Pombal, Ministro de D. José I, revela o traço marcante da filosofia jusracionalista fundada na soberania da razão humana para organizar e ordenar o mundo. Representa, portanto, a função legislativa ou normatizadora do rei caracterizada por uma "atitude racionalista" ao defender a aplicação do direito natural,

neiro: Garnier, 1880 [1 $1^{\text {a }}$ ed. 1865].

19 Alfons Aragoneses, Un jurista del modernismo. Raymond Saleilles y los orígenes del derecho comparado. Madrid: Biblioteca del instituto Antonio de Nebrija de estudios sobre la universidad, 2009, p. 12.

20 Ibid., p. 14.

21 Em pleno século XX uma decisão proferida pelo ministro Cláudio Santos no Superior Tribunal de Justiça evoca a doutrina de Pothier, jurista francês do século XVIII, para solucionar lacunas em matéria de contrato e responsabilidade civil (citado em Sylvain Soleil, Le modèle juridique français dans le monde. Une ambition (XVTe-XIXe siècle). Paris: IRJS éditions, 2014, p. 310). 
e por uma "atitude voluntarista" ao submeter o direito positivo a uma vontade guiada pela razão ${ }^{22}$. Traz, ainda, importantes ensinamentos sobre como mobilizar as fontes do direito e como interpretar essas mesmas fontes. Trata-se, portanto, de uma metanorma ${ }^{23}$, ocupando-se da aplicação de outras normas, com projeção pedagógica, porque foi ensinada nas primeiras Faculdades de Direito criadas em São Paulo e Olinda ${ }^{24}$. Representa, assim, elemento de influência para formação dos juristas brasileiros, isto perceptível em algumas obras examinadas que dedicam capítulos inteiros para explicar o sistema de fontes, atribuindo hierarquia entre elas, e também as regras da hermenêutica jurídica.

De fato, como veremos ao longo do estudo, o modo como os juristas brasileiros raciocinam e articulam seus argumentos tem fundamento no antigo pluralismo jurídico, este, por muitos séculos, teorizado em torno da dicotomia entre direito pátrio (ius proprium) e direito comum (ius commune) ${ }^{25}$. Assim, a lei de 20 de outubro de 1823, ao declarar que todo o aparato legislativo português "pela qual se regia o Brazil até 25 de abril de 1821 ... em inteiro vigor na parte em que não tiverem sido revogadas"26, trouxe o antigo pluralismo jurídico português para o Oitocentos brasileiro. Temos aqui uma dependência jurídica formal, muito embora já tivesse ocorrido a independência política em 1822. No entanto, como se verá mais adiante, os juristas brasileiros não se limitaram a aplicar o aparato jurídico do Antigo Regime português, e fizerem uso de outras fontes do direito,

22 Mário A. Cattaneo, Iluminismo e legislazione. Milão: Edizione de comunità, 1966, p. 13 e s., citado em Arno Wehling ; Maria José Wehling, "Despotismo ilustrado e uniformização legislativa. O direito comum nos períodos pombalino e pós-pombalino", Revista da faculdade de letras, v. 14, 1997, p. 416.

23 Gustavo César Machado Cabral, "A lei da boa razão e as fontes do direito: investigações sobre as mudanças no direito português do final do Antigo Regime", Anais do XIX Encontro Nacional do CONPEDI, Fortaleza - CE nos dias 09, 10, 11 e 12 de Junho de 2010, p. 6117.

24 Os Estatutos do Visconde de Cachoeira de 1825 mantiveram os ensinamentos contidos na Lei da Boa Razão, e representam a "matriz de onde se originam os textos regulamentares do nosso ensino jurídico, perdurando muitos de seus princípios até a República" (Venâncio Filho, op. cit., p. 36). Esses Estatutos serão posteriormente modificados pelo decreto 1.386 de 28 de abril de 1854 , que por sua vez, será novamente alterado pela reforma do ensino livre de 1879 (Ibid., p. 65 e s.).

25 Gustavo César Machado Cabral, Ius commune. Uma introdução à historia do direito comum do Medievo à Idade Mordena. Rio de Janeiro: Lumen juris, 2019, p. 77 e s.

26 Collecção das leis do Império do Brazil, 1823, Parte 1. Rio de Janeiro: Imprensa nacional, 1887, p. 7-8. que eles estimavam como "modernas". Durante todo o século XIX, - e mesmo até o início do século XX se presencia, assim, uma paisagem jurídica paradoxal: a vigência de variadas fontes do direito por força de lei, até que uma codificação fosse realizada e promulgada, dentro de um contexto intelectual reinado pelo positivismo ${ }^{27}$. Isto significa que o legicentrismo, princípio de base da filosofia iluminista, que pugna por um direito racional e sistematizado num único código de leis, o qual facilitaria o conhecimento de todos, tardou para se impor no Brasil, e teve de conviver ao lado de diversas normatividades, fruto de vigorosa produção legislativa extravagante, da interpretação de juízes e da doutrina. Em termos teóricos, há um tipo de tensão entre positivismo legalista e positivismo científico, ambos mergulhados no ecletismo jurídico próprio ao século $\mathrm{XIX}^{28}$. É, portanto, nesse pluralismo no século do legicentrismo que o conteúdo da Lei da Boa Razão se acomoda no Brasil.

Nesse contexto histórico-jurídico peculiar se desenvolve a técnica da comparação, verificada, neste artigo, na doutrina civilista brasileira, auxiliada pelo conceito de boa razão, relativa, também, à antiga noção de "nações civilizadas". Essa noção penetra e se expande no século XIX em conjunto com o surgimento de diferentes Estados nacionais, tendo a codificação de diversos ramos do Direito como um sinal de progresso ${ }^{29}(\mathrm{I})$. Ademais, para os juristas do Império, a primeira "nação" civilizada foi a dos romanos, cuja influência no "direito ocidental" eles reconhecem como tão importante quanto aquela do cristianismo. Aqui, o tratamento dado ao direito romano, a sua operacionalização enquanto fonte jurídica

27 A vertente jurídica do positivismo no século XIX inscreve-se nesta teorização, encontrada em Wieacker, que distingue positivismo científico e positivismo legalista. O primeiro tem como característica o desenvolvimento erudito, intelectual, do direito que funcionaria também como meio de neutralização política por meio dessa cientificidade; aqui, a doutrina tem papel importante e aparece como principal fonte produtora do direito. $\mathrm{O}$ positivismo legalista, entretanto, ganha força dentro do movimento de codificação e tende a situar a lei elaborada pelo Estado no centro do direito; é fruto desta visão racionalista herdada do século XVIII colocada em prática com a Revolução Francesa de 1789. cf. Franz Wieacker, História do direito privado moderno (tradução de António Manuel Hespanha). $3^{\text {a }}$ ed. Lisboa: Fundação Calouste Gulbenkian, 2004, p. 524-529.

28 Paisagem eclética semelhante encontrava-se na Argentina em período anterior a sua codificação civil, cf. Víctor Tau Anzoátegui, La codificación en la Argentina (1810-1870), 2ª edición revisada. Buenos Aires : Librería histórica SRL, 2008, p. 269.

29 René Hubert, "Essai sur l'histoire de l'idée de progrès", Revue d'bistoire de la philosophie et d'bistoire générale de la civilisation, $3^{\mathrm{e}}$ année, 1935 , p. $1-32$. 
subsidiária, influenciará, também, no modo pelo qual eles pensaram o direito estrangeiro (II). Antes, contudo, para melhor compreensão do presente estudo, é necessário definir "boa razão".

$$
* * *
$$

A ideia de "boa razão" remete à razoabilidade, ponderação, bom senso, no sentido de equilibrar diferentes elementos concorrentes. A boa razão equivaleria à sabedoria, o conhecimento do bem verdadeiro, este alcançado pela medida justa (juste milieu), pelo raciocínio moderado, sem excessos ou extravagância, e sem paixões. É um conceito que dá liberdade à atividade intelectual do jurista para descobrir o verdadeiro espírito e razão das leis (mens et ratio), sem se restringir unicamente a sua interpretação literal (litera legis). Das três Ordenações promulgadas no Antigo Regime português - Afonsinas, Manuelinas e Filipinas - , apenas esta última faz menção à "boa razão", as outras se limitando a empregar a expressão "conforme a razão". De fato, essas expressões remetem à antiga noção de recta ratio encontrada nos escritos dos jusnaturalistas clássicos, os quais consideravam a razão humana como um dom de Deus: o Criador dotou o ser humano de certo discernimento, de raciocínio, de compreensão do mundo ${ }^{30}$. No entanto, o ser humano é uma criatura imperfeita, marcada pelo pecado original, de modo que sua razão é limitada. Somente a razão divina é perfeita. $\mathrm{Na}$ sua imperfeição, o intelecto do ser humano se compõe de faculdades de raciocínio (razão) e de faculdades morais (virtudes). A recta ratio, que os portugueses traduziram para "boa razão”, seria uma avaliação inteligente, reta, sã, virtuosa, do mundo. Daí a ideia segundo a qual a razão deve ter um qualificativo moral para ser eficaz: "boa razão" é uma razão regida, dirigida, pela virtude, e logo justa ${ }^{31}$.

A particularidade do caso português é tentar conciliar essa visão tradicional com o iluminismo jurídico do século XVIII que vincula a razão à vontade humana para situá-la no centro da atividade legislativa ${ }^{32}$. Essa

\footnotetext{
30 Carbasse, op. cit., p. 244.

31 António Manuel Hespanha, Cultura jurídica europeia. Sintese de um milénio. Almedina: Coimbra, 2015, p. 302.

32 Ainda no início do século XIX, um dicionário publicado em Portugal desvincula "boa razão" do intelecto humano e a atrela ao direito natural, isto é, divino: "a Lei, ou he divina, isto he, prescripta por Deos, ou humana, isto he, prescripta pelos homens. A divina he, ou natural, que se conhece por meio da boa razão, ou revelada sobre o que se deve crêr, e obrar" (Joaquim José Caetano Pereira e Sousa, Esboço de bum diccionario juridico, theorético e practico, remissivo às leis compiladas, e extravagantes, t. 2. Lisboa: typographia rollandiana, $1827, V^{\circ}$ Lei).
}

tentativa de conciliação é perceptível na Lei de 18 de agosto de 1769 quando apresenta uma definição minuciosa do conceito de "boa razão", e quando estabelece que, em caso de conflito, entre direito canônico e direito pátrio, deve-se recorrer a esse último ${ }^{33}$. Muito embora o monarca tenha tentado delimitar o seu conceito, a "boa razão", como critério instrumental de hermenêutica e orientação das fontes, permanece de conteúdo aberto, flexível, elástico, o que permitiu sua sobrevivência em diferentes contextos históricos e geográficos, como é o caso do Brasil.

O conceito de "boa razão" ainda se encontra, na doutrina brasileira, apegado à visão tradicional que o liga ao direito natural, este entendido como o "complexo de leis que Deus gravou no coração do homem", conforme explica Trigo de Loureiro ${ }^{34}$. No entanto, se percebe, nos escritos de outros juristas, ligeira modulação desse conceito, como é o caso de Teixeira de Freitas. Não surpreende, em pleno século XIX, o jurisconsulto do Império ter bosquejado uma definição de "boa razão" sob a perspectiva do positivismo. Isto fica nítido quando ele opõe "boa razão" e "razão absoluta" para explicar que esta não se confunde "com a recta raz̃ão direita razão, que é a boa razãa da Lei de 18 de agosto de 1769" (em itálico no original ${ }^{35}$. Nessa distinção, ele vincula "boa razão" ao direito positivo, às leis escritas, como um elemento de orientação ao intérprete. Fazendo referência ao adágio Jus est ars boni et aequi (direito é a arte do bom e da equidade), Teixeira de Freitas não considera a lei positiva como o campo privilegiado da "razão absoluta", esta última, nas suas palavras, situada na seara da equidade. Segundo ele, "O direito positivo é transitório, progressivo... um bem relativo" que se percorre para atingir o "bem absoluto da equidade" Nessa operação intelectual, a "boa razão" aparece como ponto de apoio para alavancar a equidade que é de "razão absoluta", isto é, perfeita, inteira, soberana. Mesmo sem dizer, Teixeira de Freitas traz uma percepção do constitucionalismo moderno para considerar a "boa

\footnotetext{
33 Ver ítem 12 da Lei de 18 de agosto de 1769 (Collecção da legislação portugueza desde a última compilação das ordenações, redegida pelo desembargador Antonio Delgado da Silva. Legislação de 1763 a 1774. Lisboa: Typografia de L. C. da Cunha, 1858, p. 413).

34 Trigo de Loureiro, op. cit., t. 1, p. 18.

35 CLC, p. 275, nota. Essa distinção aparece no meio de uma explicação, em nota de rodapé, sobre o art. 394 da CLC que trata do juízo arbitral, especificamente sobre a possibilidade das partes concordarem previamente que a sentença seja executada de imediato e sem recurso algum.

36 CLC, p. 276, nota.
} 
razão" como produto do positivismo, e, por isso, transitória e reformável de modo progressivo. Percebe-se, portanto, que o conceito de "boa razão" ultrapassa os paradigmas estabelecidos na antiga legislação portuguesa para aglutinar concepções e mentalidades que são próprias ao século XIX.

$* * *$

\section{Comparatismo jurídico e ideologia do progresso}

O comparatismo jurídico, durante todo o século XIX, é fomentado pelo esforço intelectual, racional, em descobrir regras universais, a partir da confrontação dos diversos sistemas jurídicos. Inflamados pelo cientificismo da época, os jurisconsultos acreditam na existência de um direito ideal, superior e moderno, tendo como modelo de referência o direito dos países do hemisfério Norte (Europa e América do Norte), reputados como civilizados $^{37}$. As expressões "nações civilizadas", "povos cultos" ou "nações modernas", remetem à ideia de que existe um modelo ideal de humanidade, e que certas nações se encontram em estado mais avançado, mais próximo desse ideal, e que outras estão mais atrasadas no sentido de que devem transformar-se, converter-se, para atingir o modelo idealizado ${ }^{38}$. No mundo luso-brasileiro, essa visão recebe coloração religiosa para considerar como avançado e, portanto, civilizado, apenas os países que professam a religião cristã. Não é outra a opinião de Joaquim Ribas quando afirma que o modelo jurídico ideal se encontra nas leis e códigos das nações pertencentes ao "systema da civilisação christã" 39 .

Essa visão messiânica da Igreja, do seu papel civilizador da humanidade, permanece no século XIX e se adapta à ideologia do progresso ${ }^{40}$. Impulsionada pela

\footnotetext{
37 Os estudos sobre o conceito de civilização são abundantes. Ver o estudo recente de Luís Filipe Silvério Lima, "Civil, civilidade, civilizar, civilização: usos, significados e tensões nos dicionários de língua portuguesa (1562-1831)", Almanack, Guarulhos, n. ${ }^{\circ}$ 03, 2012, p. 66-81 que remete à numerosa bibliografia; e aquele de Stéphane Zékian, "Le discours du progrès dans l'Histoire de la civilisation en Europe de Guizot", Revue Française d'Histoire des Idées Politiques, 2006/1, n. ${ }^{\circ} 23$, p.55-82, que se ocupou do tema sob a perspectiva dos escritos de Guizot. Vale também indicar o estudo clássico de Lucien Febvre, Civilisation, évolution d'un mot et d'un groupe d'idées, Paris: Renaissance du Livre, 1930.

38 Febvre, op. cit., p. 23.

39 Ribas, op. cit., vol. 1, p. 194.

40 Tal como afirmava Guizot: "a ideia de progresso, do desenvolvi-
}

matriz da filosofia da história ou cronosofia ${ }^{41}$, cujos principais representantes foram Turgot e Condorcet, é uma visão de mundo que crê no movimento natural de desenvolvimento das sociedades em todos os campos possíveis - instituições sociais e políticas, língua, técnica, religião, leis, ciência, escrita, comércio, indústria etc. - e, ao mesmo tempo, projeta como ideal o atingimento de determinado estado de evolução desses diversos campos. Entre a condição de barbárie e rudeza, e aquela de sabedoria e civilidade, existem diferentes escalas de humanidade, de modo que o progresso se revela na passagem e na transformação operada entre esses dois extremos. A marcha lenta do progresso aponta sempre na direção do futuro, de modo que não existe "período histórico, categoria ou sequência de eventos históricos, que possa traduzir uma decadência, uma degeneração..." ${ }^{\prime 2}$. Trata-se de um "juízo de valor sobreposto à constatação de uma evolução histórica. Esse juízo de valor é pronunciado do ponto de vista do homem, do ponto de vista de uma humanidade que chegou a certo grau de desenvolvimento" ${ }^{43}$. Nessa visão universalista, e também otimista da humanidade, não há espaço para qualquer questionamento de viés etnocêntrico, e todos os juristas acreditam ser possível descobrir regras universais e comuns nos diversos sistemas jurídicos com vistas a atingir certo grau de progresso. A comparação, enquanto técnica jurídica, inscreve-se nessa operacionalização das fontes do direito para buscar pela "melhor" regra ou norma jurídica. Como pontua Erik Jayme, "a ideia de progresso está ligada àquelas normas jurídicas (Rechtsätren), cuja aceitação universal era considerada apenas uma questão de tempo" ${ }^{44}$. É, nesse sentido, que Teixeira de Freitas pretende encontrar, nas diversas fontes jurídicas do seu tempo, uma "unidade superior" Lafayette Rodrigues "princípios superiores"46, do mesmo modo que Trigo de Loureiro investiga nas leis um

mento [é] a ideia fundamental contida sob a palavra civilização" (Febvre, op. cit., p. 35). Alguns autores afirmam que a ideia de progresso é própria ao século XIX (cf. Jean Ehrard, L'idée de nature en France dans la première moitié du XVIIIe siècle. Paris: éditions Albin Michel en pochet, 1994, p.760), outros entendem que ela é identificável, sob diferentes matizes filosóficas, desde o século XVI (cf. Hubert, op. cit., p. 1-32).

${ }^{41}$ Hubert, op. cit., p. 5.

42 Ibid., p. 22.

43 Ibid., p. 31.

44 Erik Jayme, "Visões para uma teoria pós-moderna do direito comparado". Tradução de Cláudia Lima Marques. Cadernos do Programa de Pós-Graduação em Direito da UFRGS, v. 1, n. ${ }^{\circ} 1,2003$, p. 117.

45 CLC, p. XXXVI-XXXVII.

46 Lafayette, op. cit., p. 9. 
único e "verdadeiro sentido" 47 , e Joaquim Ribas estima que "a humanidade acha na razão o direito como noção fundamental..., como typo inalteravel... com a qual ella compara os actos de todos os agentes livres, os costumes nacionaes, as leis solemnemente decretadas, os julga e os condemna ou absolve" 48 .

Especificamente para o caso do Brasil, o pressuposto de que existem direitos de "nações civilizadas" é alimentado pelo "fantasma" da escravidão que o deixava, perante outros países, numa posição de "atraso" neste processo civilizatório ${ }^{49}$. Perdigão Malheiros alerta ao tocar no tema: “é, portanto, não só de justiça, porém da mais alta conveniencia, que seja abolida a escravidão também entre nós. As outras nações civilisadas o hão feito; e os resultados tem sanctificado tão salutar resolução" ${ }^{50}$. A "questão do elemento servil", como o tema ficou conhecido de modo abrandado à época, contribuiu, sem dúvida, para "internalizar uma condição de inferioridade, na forma de um sentimento de exclusão do mundo civilizado, ou de sua inserção nele numa condição subalterna" ${ }^{51}$. Essa visão colocava o direito brasileiro em posição periférica, de modo que a sua modernização devia, necessariamente, passar pelo modelo das instituições do "centro", isto é, dos países do hemisfério Norte, porque são reputados como mais avançados, e, logo, civilizados. Joaquim Ribas alinha o seu pensamento nesse sentido ao crer que a "América civilizada... é a continuação, ou antes nova e progressiva phase da Europa" 52 .

Essa percepção valorativa do mundo influenciou a maneira pela qual os juristas brasileiros pensaram o direito estrangeiro no século XIX. As nações consideradas como civilizadas refletem, assim, a imagem do progresso, este compreendido na sua forma mais bem-acabada, e o direito interno brasileiro o local de produções singulares, específicas, ainda distantes do ideal de progresso. Nesse sentido, não seria exagero afirmar que a comparação jurídica emerge como técnica de conhecimento e compreensão do direito pátrio à luz da experiência es-

\footnotetext{
47 Trigo de Loureiro, Instituições de direito civil brasileiro... op. cit., t. 1, p. 35 .

48 Ribas, op. cit., vol. 1, p. 49.

49 Christian Edward Cyril Lynch, "Por que pensamento e não teoria? A imaginação político-social brasileira e o fantasma da condição periférica (1880-1970)", Dados, vol. 56, n. ${ }^{\circ}$ 4, 2013, p. 735.

50 Perdigão Malheiros, A escravidão no Brasil.... op. cit.,Parte 3, 1867, p. 137.

51 Lynch, op. cit., p. 734

52 Ribas, op. cit., vol. 1, p. 307.
}

trangeira. Trata-se de uma ferramenta para identificação de regras semelhantes que possibilitaria, em seguida, a avaliação e escolha das melhores, isto é, daquelas que se encontram na via do progresso, e por meio dessa operação incentivar o avanço do conhecimento ${ }^{53}$.

\section{Comparatismo jurídico e sistema de fontes subsidiárias}

Antes de examinar como os juristas do Império operacionalizaram o sistema de fontes subsidiárias particularmente as estrangeiras — por intermédio do tratamento dado ao direito romano, convém ressaltar que, para eles, o direito português é fonte do direito pátrio. Para eles, Portugal não integra o grupo de países qualificados como "nações estrangeiras", em virtude do sentimento de pertencimento a uma mesma cultura jurídica. Perdigão Malheiros trata os autores portugueses, notadamente aqueles que escreveram após a reforma pombalina - Mello Freire, Coelho da Rocha, Borges Carneiro, Corrêa Telles - de "nossos jurisconsultos" 54 , o que demonstra apego e assimilação entre as culturas jurídicas portuguesa e brasileira, esta ainda em formação. Na mesma época, Lafayette Rodrigues afirma ter se apoiado, prioritariamente, no Código civil português, promulgado em 1867, porque tem "mais authoridade do que os outros códigos estrangeiros". Para ele, esse código reuniu e sistematizou regras do direito civil português preexistente, completando as suas lacunas "com as reformas que os progressos da sociedade exigião" 55 . Isto significa que o direito português é, para ainda usar as palavras de Perdigão Malheiros, parte integrante das "nossas ideias, usos e costumes", e não figura no quadro de fontes subsidiárias.

Os juristas brasileiros repetem o que Corrêa Telles havia escrito na sua obra Commentário crítico à Lei da Boa Razão, publicada pela primeira vez em 1824, que o direito romano constitui o primeiro corpo de "leis das nações civilizadas da Europa" ${ }^{56}$. O direito romano é

\footnotetext{
3 Erik Jayme, "Diritto comparato e teoria del progresso", Rivista del diritto commerciale e del diritto generale delle obbligazioni, 1995, fascicolo 1-4, p. 44.

54 Perdigão Malheiros, A escravidão no Brasil... op. cit., Parte 1, p. 165, nota 682 .

55 Lafayette, op. cit., p. 19, nota 16.

56 Corrêa Telles, Commentário crítico à Lei da Boa Raz̨ão... op. cit., n. ${ }^{\circ}$ 143 , p. 64.
} 
considerado como fonte estrangeira, e tratado de modo semelhante à qualquer outra legislação ou código moderno promulgado no século XIX - Código civil francês de 1804, Código civil da Lousiana de 1824, Código civil holandês de 1838, Código civil do Chile de 1855, Código civil português de 1867 , apenas para citar alguns exemplos. Todas essas fontes são estimadas como lugares possíveis de se encontrar soluções jurídicas para preencher as lacunas do direito pátrio. Mas não só os códigos. A doutrina estrangeira também recebe tratamento de fonte subsidiária. É, nesse sentido, que Perdigão Malheiros trata de forma igual direito romano e doutrina norte-americana. Para ele, a "boa razão", que incide na interpretação do direito romano, deve, também, se aplicar, por motivos semelhantes, à "doutrina da legislação da União (Sul) Americana"57.

Essa assimilação entre direito romano e direito estrangeiro moderno, ambos tratados como fontes subsidiárias, tem, inicialmente, fundamento na Lei da Boa Razão, e, posteriormente, nas regras determinadas pelos Estatutos da Universidade de Coimbra de 28 de agosto de 1772 , na parte que formula uma metodologia específica para manusear o direito romano ${ }^{58}$. Como explica Coelho da Rocha, na suas Instituições de direito civil portuguez: em primeiro lugar, deve-se verificar se a solução encontrada é fundada em "razão puramente civil", em máximas e princípios capazes de o aceitar como solução jurídica ou em regra "peculiar ao povo romano", contendo "circunstâncias dos tempos" que não existem mais; posteriormente, se consultam os usos que os jurisconsultos das nações modernas da Europa fazem dessas leis para as seguir ou refutar ${ }^{59}$. O direito romano passa a ser considerado como fonte subsidiária somente quando apresenta uma solução jurídica moderna e, portanto, civilizada.

Esse historicismo comparatista, fundado na dicotomia entre antigos e modernos, consiste em identificar uma opinião comum sobre determinado assunto, sem considerar o processo histórico e as vicissitudes do país

\footnotetext{
Perdigão Malheiros, A escravidão no Brasil... op. cit., Parte 1, p. 167. O culto à legislação estadunidense se explica pelo contexto histórico em que Malheiros escrevia sua obra, apenas dois após o fim da guerra de secessão que abolia a escravidão naquele pais.

58 Costa e Marcos, op. cit., p. 72.

59 Manuel António Coelho da Rocha, Instituições de direito civil portuguez, 4a edição. Coimbra: Livraria de J. Augusto Orcel, 1857, p. 21 22). Semelhante explicação em Perdigão Malheiros, A escravidão no Brasil... op. cit., Parte 1, p. 93; e em Trigo de Loureiro, op. cit., t. 1, p. 27.
}

onde ela foi colhida. É, portanto, esse modo peculiar de tratar o direito romano, interpretando seus textos para julgar sua modernidade, com base numa regra comum praticada por todos os códigos e legislações modernas, que reside o primeiro substrato do comparatismo jurídico no século XIX. Com efeito, os juristas brasileiros estavam muito mais preocupados em banir das fontes as regras anacrônicas, obsoletas, antigas, e distingui-las das regras modernas, atuais e conforme "....ao espírito do Direito actual, às ideias do século" ${ }^{60}$ — no dizer de Perdigão Malheiros —, do que fazer um juízo crítico sobre a particularidade do direito estrangeiro. Para eles, a ciência do direito não tem fronteiras geográficas rígidas, muito embora ela tenha delimitações temporais. Isto significa que a validade de determinada solução jurídica é resultado de exame racional de atualização e julgamento de sua modernidade ou não, isto é, seu potencial de adaptação às necessidades, ideias e progressos da época.

Assim, se a noção de "boa razão" serve de apoio para operar uma triagem em perspectiva temporal, isto é, seleção e escolha das inúmeras regras contidas no Corpus Iuris Civilis, e conservação, apenas, daquelas convergentes ao direito moderno, uma mesma preocupação inexiste para os "códigos modernos das nações civilizadas", porque a sua modernidade é presumida. Isto não significa que o direito estrangeiro tenha se revestido, entre os juristas brasileiros, de "autoridade extrínseca" - para usar uma expressão da época —, pois seu uso não é pelo simples fato de pertencer à civilização cristã. Os códigos e leis estrangeiras, bem como a doutrina que se desenvolvia apoiada neles, poderiam (e deveriam) ser objeto de crítica. A simples recepção de soluções estrangeiras, sem qualquer apreciação crítica, seria adotar postura semelhante àquela que se tinha com relação ao direito romano. Como lembra Joaquim Ribas: a Lei da Boa Razão "declarou as leis romanas privadas de força extrinseca" ${ }^{61}$, o que significa que a análise de conteúdo passa a ser condição de sua validade. A mobilização de textos estrangeiros não se perfaz por transplante sistemático, e, por isso, é necessário o estudo crítico e conhecimento prévio do direito estrangeiro. Segundo Joaquim Ribas, “...se o estudo dos escriptos dos jurisconsultos estrangeiros é um meio adequado para distinguirmos os textos antiguados do direito romano daqueles que por sua boa razão ainda estão em uso nas nações modernas,

\footnotetext{
$60 \quad$ Ibid., p. 93.

61 Ribas, op. cit., vol. 1, p. 167.
} 
por mais forte motivo deve, tambem sel-o o estudo dos codigos e leis dessas nações" ${ }^{\prime \prime}$.

Em seguida, esse mesmo autor questiona: quando leis e códigos das nações civilizadas divergirem entre si ou se contradizerem, qual adotar? Ele responde, citando Coelho da Rocha, que "neste caso a regra a seguir-se é indagar qual dessas leis ou mais se aproxima das leis e costumes patrios, quanto à instituição do direito, a cujo respeito versa o ponto da questão" ${ }^{63}$. O uso moderno das fontes do direito não significa, apenas, recolher regras conforme "às ideias do século", mas também selecionar aquelas conforme "aos costumes e índole da Nação" A escolha da solução estrangeira e sua comparação com o direito nacional torna-se meio para se atingir o conhecimento de determinada regra jurídica. Por esse modo particular de comparação, se acreditava que a "boa" solução jurídica emergiria, naturalmente, como resultado de uma síntese necessária. Nesse ponto específico, os juristas brasileiros aprofundam a técnica comparatista, porque a Lei da Boa Razão não oferecia nenhum critério objetivo no caso de as soluções do direito estrangeiro serem divergentes. Corrêa Telles já havia percebido essa insuficiência ao sugerir que, nesse caso, deve-se recorrer ao direito de uma única nação ${ }^{65}$. Se é, portanto, a partir da dicotomia "uso antiquado" e "uso moderno" que se origina a técnica de comparação jurídica, esta se situa, também, na oposição entre "direito nacional" e "direito estrangeiro", de modo que a modernização do direito brasileiro contém essas duas perspectivas.

Cabe ressaltar, enfim, que cada jurista brasileiro mobilizou as fontes estrangeiras à sua maneira, dando prevalência a certos países em detrimento de outros. Há, portanto, uma predisposição particular para reagir de maneira individual ao contato com o direito estrangeiro. Isto dependia, também, do objeto e, sobretudo, da matéria jurídica a ser tratada. A seguir, identificar-se-á, em cada uma das obras aqui trabalhadas, o método "científico" elaborado pelo jurista, e também sua explicação sobre as fontes do direito subsidiário, com especial atenção à estrangeira, a fim de sublinhar a atividade de comparação aí subjacente.

\footnotetext{
62 Ibid., p. 168-169.

63 Ibid., p. 196.

${ }^{64}$ Perdigão Malheiros, A escravidão no Brasil.... op. cit., Parte 1, p. 93.

65 Corrêa Telles, Commentário crítico à Lei da Boa Razão... op. cit., p. 68. De fato, registra-se em Portugal um caso de adoção da legislação alemã em matéria de "minas e estabelecimentos mettalicos" pelo Alvará de 30 de janeiro de 1802 (citado em Manuel Borges Carneiro, Direito civil de Portugal. Lisboa: Impressão regia, 1826, p. 60).
}

a) Trigo de Loureiro não traz, na primeira edição da suas Instituições de direito civil brasileiro de 1851, reflexão sobre o método que adotou; não traz tampouco capítulo dedicado ao sistema de fontes ${ }^{66}$. Somente na segunda edição de sua obra, publicada em 1857 — depois aparecerá uma terceira em 1871 — que se pode conhecer seu posicionamento em face do direito estrangeiro, precisamente no Capítulo III, intitulado "Noções geraes sobre as fontes do Direito civil Patrio" "67. Trigo de Loureiro afirma que "emquanto não tivermos um Codigo Civil", se deve recorrer à duas classes de fontes, a fim de evitar o uso de "fontes estranhas": as fontes "que tem fôrça de lei" e as fontes subsidiárias. Na primeira classe, ele segue a orientação da lei de 20 de outubro de 1823, para considerar todo o antigo aparato legislativo português (Ordenações, Leis, Regimentos, Alvarás, Decretos e Resoluções) e toda a legislação brasileira posterior à 1822 e, na segunda classe, as fontes subsidiárias propriamente $\operatorname{ditas}^{68}$. Nesta, ele deixa de seguir a ordem de hierarquia da Lei da Boa Razão e exclui a legislação régia para situar como primeira fonte integrativa do direito pátrio os assentos da Casa da Suplicação ${ }^{69}$, seguido dos costumes, do direito romano, da doutrina (opiniões dos jurisconsultos), dos Arestos (aqui ele não especifica o tribunal, o que pressupõe tanto o brasileiro como o português) e, por fim, as "leis das nações modernas" ". O direito estrangeiro é tratado como fonte subsidiária menor, a qual se deve recorrer por último, quando a lacuna não puder ser integrada por outra, e apenas a legislação estrangeira (leis e códigos) aparece como fonte moderna do direito. É, precisamente, no parágrafo XLII consagrado às "Leis das nações modernas" que se pode inferir uma atividade comparatista, mas ainda entendida como técnica para testar a aplicabilidade do direito romano. Nesse sentido, ele escreve que as leis e códigos "mais accreditados das nações modernas" são objeto de comparação para se escolher a melhor regra supletória das lacunas das leis pátrias, somente quando puderem

\footnotetext{
66 Lourenço Trigo de Loureiro, Instituições de direito civil brasileiro, extrabidas das instituições de direito civil lusitano do Exmo jurisconsulto portuguez Paschoal José de Mello Freire, na parte compativel com as instituições da nossa cidade, e augmentadas nos lugares competentes com a substancia das leis brasileiras pelo Doutor Lourenço Trigo de Loureiro, t. 1. Pernambuco: Typographia da viua roma e filhos, 1851.

${ }_{67}$ Trigo de Loureiro, op. cit., t. 1, 1871, p. 23.

68 Ibid., p. 23 e s.

69 A Casa de Suplicação do Brasil, criada em 1808, foi extinta em 1828, dando lugar ao Supremo Tribunal de Justiça, conforme previa a Constituição do Império de 1824. A referência aqui é, portanto, a Casa de Suplicação de Portugal.

$70 \quad$ Ibid.,p.26.
} 
ter preferência sobre o direito romano ${ }^{71}$. É o que ele faz, muito raramente ${ }^{72}$, diga-se de passagem, quando recorre às "leis das nações civilizadas", citando expressamente o Code civil de 1804, para explicar o instituto da adoção, porque as leis romanas nessa matéria são consideradas como antiguadas ${ }^{73}$.

b) Teixeira de Freitas, na sua Consolidação das leis civis, não tem capítulo consagrado às fontes do direito porque este trabalho pretende modernizar o direito civil brasileiro por meio da reunião de diversas leis esparsas e sistematização em um único lugar. É, portanto, compreensível a crítica de Teixeira de Freitas à Lei de 18 de agosto de 1769 que, para ele, "deu largas ao arbítrio com o título de boa razão", e concorreu para que os "nossos juristas carregassem suas obras de materiaes estranhos, ultrapassando mesmo as raias dos casos omissos" Sob pretexto de "mostrar o último estado da legislação", Teixeira de Freitas usa livremente inúmeras fontes do direito, inclusive estrangeira, quando convergente à "civilisação moderna", para fabricar a sua consolidação civil $^{75}$. Muito embora ainda se possa verificar, nos seus escritos, que a atividade de comparação se situa em perspectiva temporal, que consiste em "comparar attentamente as leis novas com as antigas", para "medir com precisão o alcance e as consequências de umas e outras", ele parece ir mais além. Para Teixeira de Freitas, não se trata de simples justaposição de dispositivos legais, de "comparar o texto de cada um dos artigos com lei, ou leis", mas de "achar... os limites do direito civil, a norma da exposição das materias que lhe pertencem" "76. Por isto, o jurista deve agir como um verdadeiro perito e consultar, com "livre espírito", os "monumentos le-

\footnotetext{
$71 \quad$ Ibid.,p.28.

${ }^{72} \mathrm{Na}$ obra dele, a doutrina estrangeira do Antigo Regime corresponde à $6 \%$ do total de citações, e a legislação estrangeira pósconstitucional (a dos novos códigos) representa 5\% (cf. Hespanha, "Razões de decidir na doutrina portuguesa e brasileira do século XIX”... op. cit., p. 145).

73 Trigo de Loureiro, op. cit.,p.93.

74 CLC, p. XXXII.

75 É, neste sentido, que Teixeira de Freitas enxerta na Consolidação das leis civis regras inspiradas do liberalismo europeu sem conexão com a tradição do direito luso-brasileiro. Sobre a questão, ver Ricardo Marcelo Fonseca, "Teixeira de Freitas: um jurisconsulto "traidor" na modernização jurídica brasileira”, Revista do IHGB, a. 172 (452), jul.-set., 2011, p. 350. O fenômeno pode ser considerado como "tradução cultural". Sobre esse conceito aplicado à história do direito, cf. Alfredo J. Flores e Gustavo C. Machado, "Tradução cultural: um conceito heurístico alternativo em pesquisas de história do direito", História e Cultura, Franca, v. 4, n. 3, dez. 2015, p. 118-139.

76 CLC, p. XXXVI.
}

gislativos" e as "tradições da Sciencia" para encontrar "fecundos traços [e] proposições susceptíveis dos mais ricos desenvolvimentos..." ${ }^{\prime 77}$. Se, para Teixeira de Freitas, a comparação de diferentes fontes serve para conhecer a "substância viva da legislação", ela serve, sobretudo, para encontrar uma "unidade superior que concentra verdades isoladas" $"$.

c) Perdigão Malheiros, no preâmbulo da sua $A$ escravidão no Brasil, não restringe as fontes do direito à doutrina, e faz uso abundante das decisões dos tribunais e da legislação extravagante com a finalidade de extrair os "principios fundamentaes e de maior frequencia prática" ${ }^{\text {"79 }}$. Isto porque o tema da escravidão havia sido proscrito das legislações modernas, seu método de trabalho operando através da confrontação entre tradição luso-brasileira (legislação e prática) e direito científico cujo substrato principal se encontra no Corpus iuris civilis e na interpretação posteriormente feita não só pelos modernos, mas também pela Patrística. $\mathrm{Na}$ sua obra, o direito da América do Norte, que havia recentemente abolido a escravidão, aparece como pertencente às nações civilizadas. Mas é no seu opúsculo Commentário à lei $n .^{\circ} 463$ de 2 de setembro de 1847, sobre a filiação natural, que ele recorre, com frequência, ao direito estrangeiro. Nessa obra, em veia comparatista, Perdigão Malheiros classifica as fontes do direito em "Legislações não codificadas", "Códigos anteriores ao francez" e "Código francez e posteriores" $"$. Interessante notar essa subdivisão feita pelo autor entre "leis não codificadas" e códigos propriamente ditos, tendo o Code civil de 1804 como ponto de referência importante, estimado como verdadeiro divisor de águas na matéria.

d) Lafayette Rodrigues não dedica capítulo específico para explicar o quadro de fontes, e os principais desenvolvimentos nesse tema se encontram na Introdução do seu livro Direitos de família. Apenas o direito romano é explicitamente mencionado como fonte subsidiária ${ }^{81}$, de sorte que as outras fontes referendadas na Lei da Boa Razão recebem tratamento diferente ${ }^{82}$. As Ordenações

\footnotetext{
77 Idem.

78 Ibid., p. XXXVI-XXXVII.

79 Perdigão Malheiros, A escravidão no Brasil... op. cit.,Parte 1, p.1.

80 Perdigão Malheiros, Commentário à lei $n .^{\circ} 463$ de 2 de setembro de 1847 ...op. cit., Capítulo sexto: "Direitos hereditarios dos filhos naturaes, segundo a Legislação Romana, e algumas das nações modernas", p. 58 e s.

81 Lafayette, op. cit., p. 12.

82 Ele julga como "bem pobres e mesquinhas... são as fontes do nosso Direito Civil” (Ibid., p. 9).
} 
Filipinas (antiga Legislação régia) e as leis posteriores em geral (legislação extravagante) são qualificadas de incoerentes, defectivas e disformes, devendo o jurista se valer de método "profundamente racional" 83 para deduzir princípios jurídicos, estes formados, prioritariamente, "pelos costumes, pelas decisões dos tribunaes e pela elaboração scientifica" ${ }^{\prime 4}$. Mais adiante, o uso das fontes aparece como objeto de comparação por contraste: "é á esse toque que devem de ser contrastados os costumes, as praticas forenses, as opiniões dos escriptores e as disposições paralellas dos códigos estrangeiros" $"$. Como já dito, Lafayette Rodrigues se apoia no Código civil português, recentemente promulgado à época, este servindo de referência para se descobrir o direito brasileiro, mas não descarta a possibilidade de remissão a outros códigos estrangeiros. Seu método comparativo inscreve-se, naturalmente, numa perspectiva temporal (antigos e modernos), mas Lafayette Rodrigues deixa a entender que também fez uso corrente da doutrina estrangeira quando afirma ter consultado um "grande número de escriptores antigos e modernos, nacionaes e estrangeiros. Delles adoptamos francamente as opiniões que nos parecerão mais justas..." ${ }^{86}$. É, nesse sentido, que ele se inspira no "exemplo dado pelos povos cultos" para qualificar a instituição do pátrio poder no Brasil como um "invento absurdo", já que em "França, em Portugal, no Chile e em muitos outros paizes... termina pela maioridade do filho familias" ${ }^{\prime 87}$.

e) Joaquim Ribas desenvolve, também, uma metodologia apoiada no positivismo científico, na força da doutrina para construir e elaborar sistemas racionais. $\mathrm{Na}$ parte do seu livro consagrada ao "direito das nações modernas" ( $\$ 3^{\circ}$ do Capítulo IV: Das fontes subsidiarias do direito civil - Legislação estranha), ele se apoia nas regras da lei de 18 de agosto de 1769 para afirmar que a fonte estrangeira é aplicável em dois casos: para avaliar a boa razão dos textos do direito romano, e "decidir se são ou não sanccionados pelo uso moderno"; e nas matérias políticas, econômicas, mercantis e marítimas, nas quais o direito romano não tem preferência ${ }^{88}$. Em seguida, ele lembra que, em algumas matérias, se aplica o direito estrangeiro em detrimento do brasileiro: quanto à idade e estado do estrangeiro residente no Império e sua capa-

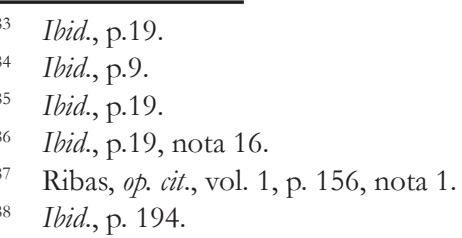

cidade para contratar, não sendo ele comerciante regido pelo Código de comércio de 1850; e quanto à forma dos contratos ajustados em país estrangeiro ${ }^{89}$. Joaquim Ribas se apresenta como verdadeiro comparatista, pois sua obra é repleta de citações de autores franceses e alemães do Antigo Regime e do século XIX, portugueses e brasileiros pós-pombalinos, os códigos francês, prussiano, austríaco, da Sardenha, e de textos do direito romano. Ele adota, enfim, uma metodologia sofisticada ao fazer uma bipartição das "nações civilizadas cristãs" em dois grandes troncos: de um lado o Código geral dos estados prussianos (Allgemeine Landrecht für die Preußischen Staaten) de 1794, e do outro o Code civil francês de 1804. Segundo Joaquim Ribas, esses códigos representam dois modelos distintos que influenciaram todos os outros que vieram depois deles ${ }^{90}$. Em seguida, ele dá alguns exemplos de matérias regulamentadas em um e outro código a fim de sublinhar suas diferenças. Nos direitos influenciados pelo código civil francês, escreve ele, a transferência do domínio é efeito pelo contrato e independente da tradição, ao passo que a exigência de registro da propriedade tem influência do código alemão. Mesmo sem dizer, Joaquim Ribas propõe uma classificação sistemática de direito comparado, o que mais tarde se denominaria "famílias jurídicas". Tanto em um como em outro tronco, pertencente à tradição cristã, e logo reputado como civilizado, é possível encontrar soluções jurídicas para preencher lacunas do direito brasileiro.

\section{Considerações finais}

Como restou demonstrado, a atividade de comparação aparece nos autores estudados como resultado do tratamento dado às fontes subsidiárias ao direito pátrio, a começar pelo direito romano e depois leis, códigos e doutrina das nações reputadas como civilizadas. Guiado pela ideologia do progresso, o comparatismo jurídico emerge, portanto, desse esforço intelectual de interpretação das diferentes fontes para encontrar, por intermédio de uma síntese geral, a norma moderna, atual e conveniente à tradição e aos costumes nacionais, e, assim, capaz de preencher a lacuna deixada pelo direito em vigor. Será preciso esperar pela criação da cadeira de "Legislação Comparada", na última década do século

\footnotetext{
$89 \quad$ Ibid., p. 195.

$90 \quad$ Ibid., p. 196-197.
} 
XIX, para que o direito comparado se desenvolva com autonomia e fora do quadro restrito do antigo sistema de fontes subsidiárias.

\section{Referências}

AIMERITO, Francesco. La comparaison comme méthode d'élaboration des lois au XIXe siècle : le cas de l'Italie (1814-1866), Cli@@Thémis,n.13,2017,pp.1-11.

ALBUQUERQUE, Martim de. Bártolo e bartolismo na história do direito português, Estudos de cultura portuguesa, $1^{\circ}$ Volume. Lisboa: Imprensa nacional-Casa da moeda, 1983, pp. 41-123.

- Jean Bodin na península ibérica. Ensaio de história das ideias politicas e de direito público. Paris: Fundação Calouste Gulbenkian, 1978.

ANZOATEGUI, Víctor Tau. La codificación en la Argentina (1810-1870), $2^{\mathrm{a}}$ edición revisada. Buenos Aires: Librería histórica SRL, 2008.

ARAGONESES, Alfons. Un jurista del modernismo. Raymond Saleilles y los orígenes del derecho comparado. Madrid: Biblioteca del instituto Antonio de Nebrija de estudios sobre la universidad, 2009.

BARDIN, Laurence. L'analyse de contenu. Paris: Presses universitaires de France (Quadrilage), 2013.

BEVILAQUA, Clovis. Resumo das liçõoes de legislação comparada sobre o direito privado. Recife: Typographia de F. P. Boulitreau, 1893.

BORGES CARNEIRO, Manuel. Direito civil de Portugal. Lisboa: Impressão regia, 1826.

BRAGA DA CRUZ, Guilherme. O direito subsidiário na bistória do direito português, Obras esparsas, volume II. Estudos de História do Direito, Coimbra, 1981.

CABRAL, Gustavo César M. Ius commune. Uma introdução à história do direito comum do Medievo à Idade Mordena. Rio de Janeiro: Lumen juris, 2019.

- A lei da boa razão e as fontes do direito: investigações sobre as mudanças no direito português do final do Antigo Regime, Anais do XIX Encontro $\mathrm{Na}$ cional do CONPEDI, Fortaleza - CE nos dias 09, 10, 11 e 12 de Junho de 2010, p. 6114-6126.

CARBASSE, Jean-Marie. Manuel d'introduction historique au droit. Paris: Puf, 2001.
COELHO DA ROCHA, Manuel António. Instituições de direito civil portuguez, $4^{a}$ ed. Coimbra: Livraria de J. Augusto Orcel, 1857.

COLLECCÃO DA LEGISLAÇÃO PORTUGUEZA desde a última compilação das ordenações, redegida pelo desembargador Antonio Delgado da Silva. Legislação de 1763 a 1774. Lisboa: Typografia de L. C. da Cunha, 1858.

COLLECCÃO DAS LEIS DO IMPÉRIO DO BRASIL, vol. 1, Parte II, 1879. Rio de Janeiro: Typographia nacional.

COLLECCÃO DAS LEIS DO IMPÉRIO DO BRAZIL, 1823, Parte 1. Rio de Janeiro: Imprensa nacional, 1887, p. 7-8.

CORRÊA TELLES, José Homem. Commentário crítico à Lei da Boa Razãa. Lisboa: Typographia de Maria da Madre de Deus, $1^{\text {a }}$ edição de 1824 (no presente estudo utilizamos a edição de 1865).

COSTA, Mário Júlio de Almeida; MARCOS, Rui Manuel de Figueiredo. A reforma pombalina dos estudos jurídicos. Boletim da Faculdade de Direito, vol. LXXV, Universidade de Coimbra, 1999, pp. 67-98.

EHRARD, Jean. L'idée de nature en France dans la première moitié du XVIIIe siècle. Paris : éditions Albin Michel en pochet, 1994.

FEBVRE, Lucien. Civilisation, évolution d'un mot et d'un groupe d'idées. Paris: Renaissance du Livre, 1930.

FONSECA, Ricardo Marcelo. Teixeira de Freitas: um jurisconsulto "traidor" na modernização jurídica brasileira. Revista do Instituto Histórico e Geográfico Brasileiro, a. 172 (452), jul.-set., 2011, pp...

FREITAS, Augusto Teixeira de. Consolidação das leis civis, publicação autorisada pelo governo, $3^{\mathrm{a}}$ edição mais augmentada, Rio de Janeiro: B. L. Garnier, Livreiro editor do Instituto Histórico, 1876.

HESPANHA, António M. Razões de decidir na doutrina portuguesa e brasileira do século XIX. Um ensaio de análise de conteúdo. Quaderni Fiorentini per la storia del pensiero giuridico moderno, n. ${ }^{\circ}$ 39, 2010, p. 109-151.

HESPANHA, António M. Cultura jurídica europeia. Sintese de um milénio. Coimbra: Almedina, 2015.

HUBERT, René. Essai sur l'histoire de l'idée de progrès. Revue d'bistoire de la philosophie et d'bistoire générale de la civilisation, $3^{\mathrm{e}}$ année, 1935, pp. 1-32. 
JAYME, Erik. Diritto comparato e teoria del progresso. Rivista del diritto commerciale e del diritto generale delle obbligazioni, 1995, fascicolo 1-4, pp. 103-118.

- Visões para uma teoria pós-moderna do direito comparado. Tradução de Cláudia Lima Marques. Cadernos do Programa de Pós-Graduação em Direito da UFRGS, v. 1, n¹, 2003, pp. 115-131.

J. FLORES, Alfredo et alii. "Tradução cultural: um conceito heurístico alternativo em pesquisas de história do direito". História e Cultura, v. 4, n. 3, dez. 2015, p. 118 139.

LIMA, Luís Filipe Silvério. Civil, civilidade, civilizar, civilização: usos, significados e tensões nos dicionários de língua portuguesa (1562-1831). Almanack, Guarulhos, n. ${ }^{\circ}$ 03, 2012, p. 66-81.

LYNCH, Christian Edward Cyril. Por que pensamento e não teoria? A imaginação político-social brasileira e o fantasma da condição periférica (1880-1970). Dados, vol. 56, $\mathrm{n}^{\circ} 4,2013$, pp. 727-767.

MARCOS, Rui Manuel de Figueiredo. A legislação pombalina. Alguns aspectos fundamentais. Coimbra: Almedina, 2006.

Memorias de litteratura portugueza, publicadas pela Academia Real das Sciencias de Lisboa, t. 1. Lisboa: Officina da Academia Real de Sciencias, 1782, §LIV, p. 328.

PERdiGÃO MALHEIROS, Agostinho Marques. A escravidão no Brasil. Ensaio histórico-jurídico-social, 3 vols. Rio de Janeiro: Typographia Nacional, 1867.

. Commentário à lei $n .{ }^{\circ} 463$ de 2 de setembro de 1847 sobre successão dos filhos naturaes e sua filiação. Rio de Janeiro: Eduardo e Henrique Laemmert, 1857.

PEREIRA, Lafayette Rodrigues. Direitos de família. Rio de Janeiro: typographia franco-americana, 1869.

PEREIRA E SOUSA, Joaquim José Caetano. Esboço de bum diccionario juridico, theorético e practico, remissivo às leis compiladas, e extravagantes, t. 2. Lisboa: typographia rollandiana, $1827, \mathrm{~V}^{\circ}$ Lei.

RANGEL, Alan. O projeto de Teixeira de Freitas: um código civil antinapoleônico ? Contribuição ao estudo do comparatismo jurídico no século XIX. In: Arno Wehling, Gustavo Siqueira, Samuel Barbosa (orgs.), História do direito. Entre rupturas, crises e descontinuidades. Belo Horizonte: Arraes, 2018, p. 165-183.

RIBAS, Antonio Joaquim. Curso de direito civil, 2 vols. Rio de Janeiro: Garnier, 1880 [1ª ed. 1865].

SEELAENDER, A. L. C. L.. A doutrina estrangeira e o jurista brasileiro: usos, estratégias e recriações. In: Carolina Alves Vestena; Gustavo Silveira Siqueira. (Org.). Direito e experiências jurídicas- Temas de história do direito. 1ed. Belo Horizonte: Arraes, 2013, v. 3, p. 1-17.

SOLEIL, Sylvain. Le modèle juridique français dans le monde. Une ambition (XVTe-XIXe siècle). Paris: IRJS éditions, 2014.

TRIGO DE LOUREIRO, Lourenço. Instituições de direito civil brasileiro, 2 tomos. Rio de Janeiro: Garnier, $3^{\text {a }}$ ed., 1871 [1 $1^{\text {a }}$ ed. 1851].

VENÂNCIO FILHO, Alberto. Das arcadas ao bacharelismo. São Paulo: editora perspectiva, 1977,

VILLEY, Michel. La formation de la pensée juridique moderne. Paris: Quadrilage - Puf, 2006,

WEHLING, Arno; WEHLING, Maria José. Despotismo ilustrado e uniformização legislativa. $\mathrm{O}$ direito comum nos períodos pombalino e pós-pombalino. Revista da faculdade de letras, v. 14, 1997, pp. 413-428.

WIEACKER, Franz. História do direito privado moderno (tradução de António Manuel Hespanha). 3a edição. Lisboa: Fundação Calouste Gulbenkian, 2004.

ZEKIAN, Stéphane. Le discours du progrès dans l'Histoire de la civilisation en Europe de Guizot, Revue Française d'Histoire des Idées Politiques, 2006/1, n. ${ }^{\circ} 23$, p. 55-82. 
Para publicar na Revista de Direito Internacional, acesse o endereço eletrônico www.rdi.uniceub.br ou www.brazilianjournal.org.

Observe as normas de publicação, para facilitar e agilizar o trabalho de edição. 